\title{
Prevalence of Behavioral Risk Factors of Noncommunicable Diseases in a Rural Population of Bangladesh
}

\author{
Chandra Banik P*, Mostafa Zaman M, Ahmed J \\ and Reza Choudhury S \\ Department of Noncommunicable Diseases, Ekhlaspur \\ Centre of Health (ECOH), Bangladesh \\ *Corresponding author: Chandra Banik P, \\ Department of Noncommunicable Diseases, Ekhlaspur \\ Centre of Health (ECOH), Bangladesh
}

Received: December 05, 2016; Accepted: February 09, 2017; Published: February 14, 2017

\begin{abstract}
Behavioral risk factors reduction is a key to Noncommunicable Diseases (NCDs) control. This survey on NCD risk factors was done in randomly selected cross-sectional sample of 443 rural individuals aged 15 years or older. More than three in ten people used tobacco in some form, and more than nine in ten used extra salt while taking meal. All of them had low fruit and vegetables intake ( $<5 \mathrm{gm} /$ day). About four and one percent were taking medicines for hypertension and diabetes, respectively. In conclusion, prevalence of tobacco and added salt consumption is fairly high in this rural Bangladeshi sample. Local level health infrastructure and health workers should be used to control these risk factors in rural communities.
\end{abstract}

Keywords: Non-communicable disease risk factors; Rural community; Bangladesh

\section{Introduction}

Non-Communicable Diseases (NCDs) are plaguing both developed and developing countries. Tobacco use, physical inactivity, harmful use of alcohol, low consumption of fruit and vegetables and high intake of saltare first line risk factors in Bangladesh and these are generally targeted for NCD control [1,2]. If these risk factors can be controlled at first hand, NCDs could be largely controlled. Health system in Bangladesh is yet to come up with risk factor approach of NCD prevention. In spite of adequate human resource at community level, screening are not done routinely [3]. Before executing any screening and risk factor reduction intervention, it is necessary to know the actual situation at the community. Therefore present study was carried out to determine the prevalence of these risk factors in a village of Bangladesh.

\section{Methods}

This study was done in 2011 among residents aged 15 years or older of Ekhlaspur village (Chandpur district). Ekhlaspur Center of Health (ECOH), a non-profit community based non-governmental health care provider has been conducting health examinations in Ekhlaspur since 2001. Ekhlaspur has a total of 1088 households [4]. Five hundred households were approached randomly and one eligible person per household was selected using Kish method [5].

Questions on tobacco (smoking and smokeless) use asked. Amount of added salt while taking meal, fruit and vegetables intakes were determine showing, spoons, cups and show-cards. History of current medication for hypertension and diabetes was obtained. Data were collected by experienced local health assistants of $\mathrm{ECOH}$.

Verbal consent was obtained from the respondents. Prevalence (95\% confidence interval) of risk factors were obtained, which were adjusted to WHO's world standard population.

\section{Results}

Altogether 443 adults (225 men, and 218 women) participated. The mean age and schooling of respondents was 40 years and 5 years respectively. Results are presented in (Table 1). Overall age standardized prevalence of current smoking and smokeless tobacco use was $17.5 \%$ and $20.2 \%$ respectively. Women did not smoke but used smokeless tobacco (27.4\%) more than men did (13.8\%). Prevalence of taking added salt was very high (93.2\%). None of them took minimum 5 servings of fruit and vegetables/day. As defined by history of current medication, age standardized prevalence of hypertension and diabetes was $3.7 \%$ and $1.0 \%$ respectively.

\section{Discussion}

Although a small and single location study, like this one has its inherent limitations for generalizability but our findings indicate that local level health workers could be useful in collecting risk factor data.

Our most striking finding is low intake of fruit and vegetables by all respondents, which is not so far from national data (98\%) [6]. This is consistent with data from India [7] and Nepal [8]. We, in fact, expected a little lower prevalence because this study was conducted in a remote village. Prevalence of both smoking and smokeless tobacco use is high in men, but similar to India and Nepal [7-8]. However, these prevalence are lower than national level findings [6] because of ongoing anti-tobacco campaign of ECOH.

Hypertension and diabetes are major risk factors of stroke and heart attacks. Although hypertension (prevalence, 20\% [9]) and diabetes (prevalence 6\% [10]) common problems in rural areas of Bangladesh, their treatment status is far from adequate in this community. There is a need to explore the reasons for such a low treatment rate. A very high dietary salt intake (17 gm/day) [11] should receive adequate attention for community interventions. 
Table 1: Prevalence of behavioral risk factors for NCDs among residents of Ekhlaspur village.

\begin{tabular}{|c|c|c|c|c|c|c|c|c|}
\hline Age (year) & $\begin{array}{l}\text { Number of } \\
\text { subjects }\end{array}$ & Smoking & $\begin{array}{l}\text { Smokeless } \\
\text { tobacco use }\end{array}$ & $\begin{array}{l}\text { Tobacco use } \\
\text { in any form }\end{array}$ & $\begin{array}{c}\text { Use of } \\
\text { extra salt } \\
\text { on the } \\
\text { table }\end{array}$ & $\begin{array}{c}\text { Fruit/ vegetables } \\
<5 \text { servings } \\
\text { consumption per } \\
\text { week }\end{array}$ & $\begin{array}{l}\text { History of } \\
\text { medication for } \\
\text { hypertension }\end{array}$ & $\begin{array}{c}\text { History of } \\
\text { medication for } \\
\text { diabetes mellitus }\end{array}$ \\
\hline \multicolumn{9}{|c|}{ Men and women } \\
\hline $15-24$ & 72 & 5.6 & 1.4 & 6.9 & 90.3 & 100 & 0 & 0 \\
\hline $25-34$ & 92 & 9.8 & 6.5 & 15.2 & 91.3 & 100 & 3.3 & 0 \\
\hline $35-44$ & 107 & 18.7 & 17.8 & 34.6 & 95.3 & 100 & 0 & 0.9 \\
\hline $45-54$ & 88 & 36.4 & 26.1 & 56.8 & 88.6 & 100 & 2.3 & 0 \\
\hline $55-64$ & 42 & 19 & 52.4 & 61.9 & 97.6 & 100 & 9.5 & 4.8 \\
\hline $65+$ & 42 & 26.2 & 47.6 & 61.9 & 92.9 & 100 & 14.3 & 2.4 \\
\hline Total (Crude) & 443 & $\begin{array}{c}19.0 \\
(15.3-22.7)\end{array}$ & $20.5(16.7-24.3)$ & $\begin{array}{c}35.7 \\
(31.2-40.2)\end{array}$ & $\begin{array}{c}92.3 \\
(89.8-94.8)\end{array}$ & $100(100-100)$ & $3.4(1.7-5.1)$ & $0.9(0.02-1.8)$ \\
\hline $\begin{array}{c}\text { Total } \\
\text { (Age stadardized)\# }\end{array}$ & 443 & $\begin{array}{c}17.5 \\
(14.0-21.0)\end{array}$ & $20.2(16.5-23.9)$ & $\begin{array}{c}33.8 \\
(29.4-38.2)\end{array}$ & $\begin{array}{c}92.3 \\
(89.8-94.8)\end{array}$ & $100(100-100)$ & $3.7(1.9-5.5)$ & $1.0(0.1-1.9)$ \\
\hline $\begin{array}{c}25-64 \\
\text { (Age standardized)\# }\end{array}$ & 329 & $\begin{array}{c}20.1 \\
(16.4-23.8)\end{array}$ & $22(18.1-25.9)$ & $\begin{array}{c}38.2 \\
(33.7-42.7)\end{array}$ & $\begin{array}{c}92.9 \\
(90.5-95.3)\end{array}$ & $100(100-100)$ & $3.2(1.3-5.1)$ & $1.1(0.0-2.2)$ \\
\hline \multicolumn{9}{|l|}{ Men } \\
\hline $15-24$ & 37 & 10.8 & 0 & 10.8 & 86.5 & 100 & 0 & 0 \\
\hline $25-34$ & 37 & 24.3 & 2.7 & 24.3 & 89.2 & 100 & 0 & 0 \\
\hline $35-44$ & 55 & 36.4 & 16.4 & 49.1 & 94.5 & 100 & 0 & 1.8 \\
\hline $45-54$ & 55 & 58.2 & 10.9 & 60 & 83.6 & 100 & 3.6 & 0 \\
\hline $55-64$ & 18 & 44.4 & 33.3 & 55.6 & 94.4 & 100 & 5.6 & 11.1 \\
\hline $65+$ & 23 & 52.2 & 43.5 & 69.6 & 91.3 & 100 & 13 & 4.3 \\
\hline Total (Crude) & 225 & $\begin{array}{c}37.3 \\
(31.0-43.6)\end{array}$ & $14.2(9.6-18.8)$ & $\begin{array}{c}44.0 \\
(37.5-50.5)\end{array}$ & $\begin{array}{c}89.3 \\
(85.3-93.3)\end{array}$ & $100(100-100)$ & $2.7(0.6-4.8)$ & $1.8(0.1-3.5)$ \\
\hline $\begin{array}{c}\text { Total } \\
\text { (age stadardized)\# }\end{array}$ & 225 & $\begin{array}{c}34.1 \\
(27.9-40.3)\end{array}$ & $13.8(9.3-18.3)$ & $\begin{array}{c}39.9 \\
(33.5-46.3)\end{array}$ & $\begin{array}{c}89.5 \\
(85.5-93.5)\end{array}$ & $100(100-100)$ & $2.6(0.5-4.7)$ & $2.1(0.2-4.0)$ \\
\hline $\begin{array}{c}25-64 \\
\text { (age standardized)\# }\end{array}$ & 165 & $\begin{array}{c}39 \\
(32.6-45.4)\end{array}$ & $13.6(9.1-18.1)$ & $\begin{array}{c}44.9 \\
(38.4-51.4)\end{array}$ & $\begin{array}{c}90.3 \\
(86.4-94.2)\end{array}$ & $100(100-100)$ & $1.8(0.0-3.8)$ & $2.4(0.1-4.7)$ \\
\hline \multicolumn{9}{|l|}{ Women } \\
\hline $15-24$ & 35 & 0 & 2.9 & 2.9 & 94.3 & 100 & 0 & 0 \\
\hline $25-34$ & 55 & 0 & 9.1 & 9.1 & 92.7 & 100 & 5.5 & 0 \\
\hline $35-44$ & 52 & 0 & 19.2 & 19.2 & 96.2 & 100 & 0 & 0 \\
\hline $45-54$ & 33 & 0 & 51.5 & 51.5 & 97 & 100 & 0 & 0 \\
\hline $55-64$ & 24 & 0 & 66.7 & 66.7 & 100 & 100 & 12.5 & 0 \\
\hline $65+$ & 19 & 0 & 52.6 & 52.6 & 94.7 & 100 & 15.8 & 0 \\
\hline Total (Crude) & 218 & 0 & $27.1(21.2-33.0)$ & $\begin{array}{c}27.1 \\
(21.2-33.0)\end{array}$ & $\begin{array}{c}95.4 \\
(92.6-98.2)\end{array}$ & $100(100-100)$ & $4.1(1.5-6.7)$ & $0.0(0.0-0.0)$ \\
\hline $\begin{array}{c}\text { Total } \\
\text { (age stadardized)\# }\end{array}$ & 218 & 0 & $27.4(21.5-33.3)$ & $\begin{array}{c}27.4 \\
(21.5-33.3)\end{array}$ & $\begin{array}{c}95.4 \\
(92.6-98.2)\end{array}$ & $100(100-100)$ & $4.3(1.6-7.0)$ & $0.0(0.0-0.0)$ \\
\hline $\begin{array}{c}25-64 \\
\text { (age standardized)\# }\end{array}$ & 164 & 0 & $31.6(25.4-37.8)$ & $\begin{array}{c}31.6 \\
(25.4-37.8)\end{array}$ & $\begin{array}{c}95.9 \\
(93.3-98.5)\end{array}$ & $100(100-100)$ & $3.9(0.9-6.9)$ & $0.0(0.0-0.0)$ \\
\hline $\begin{array}{c}x^{2 / p} \\
\text { (men compared to } \\
\text { women) }\end{array}$ & & 0.001 & 0.001 & 0.001 & 0.016 & --- & 0.4 & 0.12 \\
\hline
\end{tabular}

"Values in the parentheses are 95\% confidence intervals

\#Standardized to the age distribution of the new WHO world standard population (2000-2025)

Men and women were compared using Chi-square test. 


\section{Conclusion}

Although this is a snapshot of this rural population it gives us alarming picture of high tobacco and salt intake, and low intake of fruit and vegetables and low treatment rates of hypertension and diabetes in remote communities of Bangladesh. Community level health facilities/organizations should be utilized for controlling NCD risk factors in Bangladesh.

\section{References}

1. World Health Organization. Revised WHO Discussion Paper: A Comprehensive Global Monitoring Framework, Including Indicators, and a Set of Voluntary Global Targets for the Prevention and Control of Noncommunicable Diseases. 2012.

2. World Health Organization. The World Health Report 2002: Reducing Risks, Promoting Healthy Life. Geneva: WHO. 2002; 1-230.

3. Zaman MM, Ullah AKMJ, Bhuiyan MR, Karim MN, Moniruzzaman, Rahman SMA. Noncommunicable Disease Prevention and Control Situation in a Primary Health Care Setting of Bangladesh: Design and Baseline Findings of an Intervention. Chronic Dis Int. 2016; 3: 1021.

4. Zaman MM, Choudhury SR, Ahmed J, Hussain SM, Sobhan SM, Turin TC Prevalence of Stroke in a Rural Population of Bangladesh. Global Heart. 2015.
5. Kish LA. Procedure for objective respondent selection with the household. J Am Stat Assoc. 1949; 44: 380-387.

6. Zaman MM, Bhuiyan MR, Karim MN, Moniruz Zaman, Rahman MM Akanda AW, et al. Clustering of non-communicable diseases risk factors in Bangladeshi adults: An analysis of STEPS survey 2013. BMC Public Health 2015: 15: 659 .

7. Thakur JS, Jeet G, Pal A, Singh S, Singh A, Deepti SS, et al. Profile of Risk Factors for Non-Communicable Diseases in Punjab, Northern India: Results of a State-Wide STEPS Survey. PLoS ONE. 2016; 11: e0157705.

8. Aryal KK, Mehata S, Neupane S, Vaidya A, Dhimal M, Dhakal P, et al. The Burden and Determinants of Non Communicable Diseases Risk Factors in Nepal: Findings from a Nationwide STEPS Survey. PLoS ONE 10: e0134834.

9. Chowdhury S, Chowdhury P. Prevalence of Hypertension among the Bangladeshi Adult Population: A meta-analysis of Studies between 2004 and 2014. Cardiovasc J. 2015; 7: 104-107.

10. Fatema K, Zwar NA, Milton AH, Ali L, Rahman B. Prevalence of Risk Factors for Cardiovascular Diseases in Bangladesh: A Systematic Review and MetaAnalysis. PLoS ONE. 2016; 11: e0160180.

11. Zaman MM, Choudhury SR, Ahmed J, Khandker RK, Rouf MA, Malik A. Salt intake in an adult population of Bangladesh. Global Heart. 2016; 2211-8160.
Austin J Public Health Epidemiol - Volume 4 Issue 1 - 2017 ISSN : 2381-9014 | www.austinpublishinggroup.com Banik et al. (C) All rights are reserved
Citation: Chandra Banik P, Mostafa Zaman M, Ahmed J and Reza Choudhury S. Prevalence of Behavioral Risk Factors of Noncommunicable Diseases in a Rural Population of Bangladesh. Austin J Public Health Epidemiol. 2017; 4(1): 1054 